\title{
Miran Spelič
}

\section{Jerome and Victorinus:}

\section{A Complex Relationship Between the Compatriots}

\section{Hieronim in Viktorin: Zapleten odnos med rojakoma}

Abstract: The paper is based on an analysis of the adjective noster as an attribute to the proper name; its use by Jerome in a short note found in De viris illustribus serves to broaden the otherwise scarce information on his compatriot Victorinus. In Jerome's other references to Victorinus, too, a friendly bias can be noticed, as Jerome, otherwise highly critical and anti-heterodox turns a blind eye to Victorinus' millennialism. Jerome criticises Victorinus only for his stylistic shortcomings and linguistic imperfection and tones this down further by praising Victorinus' command of Greek. Jerome's judgments also say something about Jerome himself: although he broke away from his homeland early and became a true cosmopolitan, he nevertheless retained a special connection to his native land and its inhabitants.

Keywords: Jerome, Victorinus of Poetovio, millennialism, Latin exegesis

Povzetek: V članku izhajamo iz analize svojilnega pridevnika »noster « kot epiteta $\mathrm{k}$ lastnemu imenu. Iz njegove rabe pri Hieronimu skušamo poglobiti razumevanje kratke notice o Viktorinu iz Hieronimovega dela De viris illustribus, v kateri nam daje sicer skope, a dragocene podatke o svojem rojaku. Tudi pri drugih Hieronimovih omembah Viktorina zasledimo prijazno pristranskost, saj sicer zelo kritičen in proti heterodoksnosti nastrojen Hieronim tukaj zamiži na eno oko in spregleda Viktorinov milenarizem - očita mu le slogovno nedodelanost in jezikovno nedovršenost, pa še to omiljuje s pohvalo njegovega znanja grščine. Hieronimove sodbe povedo nekaj tudi o njem samem: čeprav se je zgodaj odtrgal od domače dežele in bil pravi svetovljan, je do domače dežele in njenih prebivalcev vendarle ohranjal poseben odnos.

Ključne besede: Hieronim, Viktorin Ptujski, milenarizem, latinska eksegeza

Whenever Jerome wanted to show special kindness to someone, he gave them the attribute noster ,our'; a few times, he even paraphrased this pronoun with the form meus et tuus, , my and your'. He often treated his friends in this way; only sometimes, however, he qualified people from the past with this attribute. Those 
were, without exception, Christian authors. Within Jerome's rather extensive opus with many names mentioned, only Hilary of Poitiers and Victorinus of Poetovio are given this kind of attention three times.

The present paper aims to point out some links that may have contributed to a particular relationship between Jerome and Victorinus, and explain the reasons behind it. We started our research simply by analyzing all the occurrences of the possessive pronoun noster applied to personal names and later all mentions of Victorinus of Poetovio in Jerome's writings. ${ }^{1}$ We found three occurrences that belong to both lists, and we think that is rather meaningful.

\section{Jerome's Usage of the Adjective noster}

Jerome was not always an easy character. On the one hand, he was extremely polite and courteous towards his friends, but on the other, he was even able to call his opponents names (Opelt 1965, 1973). One of his frequent courtesies was the possessive pronoun noster, and two of his contemporaries who enjoyed that privilege were Nepotianus and Blesilla. The former had been his correspondent, and both are mentioned in his letters to other people, ${ }^{2}$ and both were deceased; it is in their epitaphs, full of admiration, that Jerome uses this pronoun so frequently. Both these letters, 39 and 60, are in some way unofficial canonization of the mourned persons. They are full of respect for Nepotianus' virtuous life or Blesilla's profound conversion. In short, we can define their literary genre as a true Christian apotheosis.

The second group that receives this type of treatment is Christian authors from the past; only two of these are Greek writers, the majority of them are Latin writers (Ep. 49.19). They are listed here in alphabetic order: rather pagan Ausonius (118.7), Cyprian of Carthage, Hilary of Poitiers (20.1; 34.5; 49.19), Lactantius, borderline orthodox Novatian, Tertullian of the same sort (36.1), and, finally, our Victorinus of Poetovio. In this last case, ,our' may simply refer to ,Latin' or may pertain to Victorinus being a companion in Christian literary effort. Or, perhaps it has some deeper meaning.

Jerome sometimes uses the analyzed pronoun noster in a geographical sense since we find it used twice with the place of his residence, Bethlehem nostra $(58.3 ; 65.1)$.

When Jerome uses the possessive pronoun noster with the name of his exegetical forerunner Victorinus, he surely refers to his sanctity, which Victorinus gained through his undoubted martyrdom. Here, he is joined by Nepotianus $(60.1 ; 60.8$; $60.11 ; 60.19)$ and Blesilla $(38.2 .5 ; 39.3 ; 39.7)$. Furthermore, Victorinus is also one of the respected Latin Christian authors, the first to give us exegetical writing, so

\footnotetext{
All Jerome's mentions of Victorinus have already been collected by Haussleiter (1916, VII-XIV). See also Micaelli 1995.

2 To Nepotianus Ep. 52, Epitaph of Nepotianus in Ep. 60 to Heliodorus. Blesilla mentioned in Ep. 38; Epitaph for Blesilla in Ep. 39 to Paula, her mother. For the Latin citations from Jerome's letters, the Hilberg's CSEL critical edition is quoted.
} 
he belongs to the group of the other Church fathers. ${ }^{3}$ Moreover, Victorinus may also be noster through the geographic vicinity of their homelands: Poetovio being colonia Pannoniae, and Strido (or Stridonae) oppidum, quod Dalmatiae Pannoniaeque confinium fuit (De vir. ill. 135).

\section{Jerome's Attitude Towards , his' Victorinus}

Victorinus of Poetovio gets average attention in Jerome's Illustrious Men; he is neither overlooked nor overexposed. ${ }^{4}$ Besides the admittedly incomplete list of Victorinus' writings, we are informed of his bishopric in Poetovio, of his blessed death as a martyr, and we get one single literary evaluation: about his not-perfect knowledge of Latin. However, at the same time, this criticism is toned down by two instances of praise: his command of Greek (non aeque Latine ut Graece noverat), and the importance of his work (opera grandia sensibus). The general impression that Jerome conveys is relatively positive. Without neglecting or minimizing Victorinus' shortcomings, Jerome praises him.

Victorinus is one of the few Latin Christian authors who deserved praise in Jerome's quotes. In letters 58 and 70, Jerome gives an abstract of his Illustrious Men, but with slight modification. Thus, in Ep. 58, he tells of Victorinus' martyrdom and his inability to put into words all he knows (quod intellegit, eloqui non potest). In Ep. 70, Jerome clearly defines the reason for Victorinus' weakness: his lack of erudition (licet desit eruditio, tamen non deest eruditionis voluntas), which he hoped to improve on, but obviously failed to do so due to his situation and different circumstances. Again, Jerome's criticism is not merciless but relatively gentle.

He mentions Victorinus as one of many Origen's translators into Latin (Hilary, Eusebius of Vercelli, himself). In Ep. 61 and 84, he praises Victorinus' writings, not as mere translations, but as authorial works (nec disertiores sumus Hilario nec fideliores Victorino, qui tractatus eius non ut interpretes, sed ut auctores proprii operis transtulerunt). He parallels Victorinus to Origen, saying that their exegesis is similar in specific points.

Jerome admired Victorinus as the only Latin interpreter of Isaiah. Nevertheless, again, Jerome could not resist a slight criticism regarding Victorinus' style, but he softens this by drawing a comparison to the apostle Paul, whose autobiographical remark he uses for the Pannonian bishop, praising his knowledge. ${ }^{5}$

\footnotetext{
See Hier., Ad Gen. 27,27: „Hippolyti martyris verba ponemus, a quo et Victorinus noster non plurimum discrepat. " (cf. also Id., Ep. 36.16); Id., Ep. 18.6: „Victorinus noster duodecim Apostolos interpretatus est."

$4 \quad$ Hier., De vir. ill. 74: "Victorinus, Petavionensis episcopus, non aeque Latine ut Graece noverat. Unde opera eius grandia sensibus, viliora videntur compositione verborum. Sunt autem haec: Commentarii in Genesim, in Exodum, in Leviticum, in Isaiam, in Ezechiel, in Abacuc, in Ecclesiasten, in Cantica Canticorum, in Apocalypsim loannis, adversum omnes haereses, et multa alia. Ad extremum martyrio coronatus est."

5 In Isaiam prol.: "... etsi imperitus sermone, non tamen scientia."
} 


\section{The Question of Millennialism and Victorinus' Exegesis of the Apocalypse}

However, what is truly astonishing is Jerome's tolerance towards Victorinus' millennialism or chiliasm. Jerome has been known for his low tolerance of heterodoxy, to which millennialism belonged in his times; however, this belief seems to enjoy a special place in Jerome's judgments. Millennialism was commonly believed in by very authoritative persons, such as Justin, Irenaeus, and Tertullian. One of them is also our Victorinus. As Jerome could not criticise Irenaeus, he also did not reproach Victorinus for his millennialism. He nevertheless mentioned it a few times and did not simply ignore this view by Victorinus.

Another reason for such careful treatment seems to be that millennialism was not so strong or maybe not even present anymore in Jerome's time. ${ }^{6}$ So it did not present any real threat to orthodoxy, as did Arianism, the remains of which may have persisted at the time.

Jerome's mentions of Victorinus are most commonly found in the lists of Christian authors. At least eleven of them can be attested. Three times he is mentioned as part of a group of those who explain the Apocalypse in a millennialistic manner (e.g. Hier., De vir. ill. 18; In Ezech. 11). Four times Victorinus is one of the two authors who are compared in one way or another.

The rest of the occurrences are characterizations of Victorinus as a translator of Origen (three times), a martyr with a pleasant temper (nulli molitur insidias) (Hier., $A d v$. Ruf. 1.2); there are two further mentions of Victorinus' exegeses by Jerome.

The two authors came closest when Jerome decided not to write his own commentary on the Apocalypse or to do it only later, time and circumstances permitting. The fact is that he never did. Instead, he just revised Victorinus' work. In our opinion, he tried to conceal his discomfort at avoiding this challenging task by writing in the preface that he was only answering a question posed by his friend Anatolius inquiring about his opinion on Victorinus' interpretation, which had been sent to him. Nevertheless, Jerome ended up doing more than he was asked to do, not only writing a review but also correcting the text where it had been, as he supposed, made faulty by the scribes and, above all, replacing the final chapters. In the preface, he explained these reasons and his methods, especially with regard to Victorinus' millennialism. Jerome also promised to replace the last chapters, which were impregnated by millennialism.

To make absolutely clear where his own text begins, Jerome makes the sign of the cross there. ${ }^{7}$ Thus, Jerome's care for orthodoxy led to the loss of Victorinus' basic millennial text since all the surviving copies bear Jerome's finale. However, we are incredibly fortunate that at least one manuscript containing Jerome's introduction

6 The millenarian error was first closely linked to Biblical exegesis (Rev. 20), as well as to eschatological rhetoric. See also Krašovec 2020 and Avsenik Nabergoj 2020.

7 Hier., Pref. In Apoc.: "A principio libri usque ad crucis signum quae ab imperitiis erant scriptorum vitiata, correximus, exinde usque ad finem voluminis addita esse cognosce." 
lacks his replacement of the comment of the last chapters and includes Victorinus' original text instead. So, since Hausleiter's edition in CSEL 49 of 1916, we can observe directly what type of millennialism Victorinus pursued. (Dulaey 1993)

As we mentioned already, we are amazed by Jerome's meek attitude towards Victorinus. He could have ground him to dust, and Victorinus could not have answered back. Jerome could have signed his own name under the corrected version, but the Stridonian (i.e. Dalmato-Pannonian) respected the authorship of the Pannonian. Perhaps there was at least a hint of patriotism and loyalty to his homeland that made Jerome judge Victorinus more mildly than he would otherwise have done.

Curti, in his article, concludes that Jerome tolerated Victorinus' millennialism and paid respect to him because he mitigated those eschatological views with allegorical exegesis; but Jerome remained a harsh opponent of iudaizantes and literalists. (Curti 1998, 202)

\section{Conclusion}

Victorinus and Jerome never met in earthly life since half of the century had elapsed between the death of the former and the birth of the latter. There were many differences between them. The former, who could not afford classical education, still experienced persecution and was martyred; the latter, well trained in Classics, enjoyed the freedom of religion, witnessed the golden age of patristics and got his star on the ecclesiastic, walk of fame' soon. Though he may have travelled widely, the former ended up staying in a relatively secluded town, Poetovio, at the edge of the empire. The latter crossed roads and seas from one lime to another, made himself quite at home in Constantinople and Rome, and towards the end of his life, wrote letters all over the world from Bethlehem. The former lived in an era of establishing orthodoxy and stabilizing the canon. The latter was a contemporary and colleague of Epiphanius, the heresy-hunter, and received the heritage of the first two ecumenical councils. However, they were both scrutators of the Bible, and through their literary and exegetical efforts, they transmitted the Word from one context to another. Moreover, both were also geographically close to each other. ${ }^{8}$

Jerome could have judged Victorinus much more severely, not only on the grounds of his literary weakness and lack of formal education but rather on the grounds of his questionable eschatological belief. Nevertheless, he treated him with unusual kindness and sympathy. Two possible reasons for this can be assumed. The crown of martyrdom assured Victorinus of an unquestionable place in heaven, so Jerome did not hesitate to lean on him, regardless of millennialism, which was no longer a threat in his time. Maybe Jerome, who was so reserved

8 The importance of this wide but well connected geographical area is also demonstrated by Jerome's familiarity with of the work of Bishop Fortunatianus of Aquileia, which was only rediscovered in 2012 after fifteen centuries in oblivion. See Bogataj 2020; Bogataj and Špelič 2020. 
with positive expressions about his homeland, gives at least some praise to his compatriot, granting him this attribute of honour and neighbourliness: noster.

\section{Abbreviations}

Adv. Ruf. - Adversus Rufinum.

CSEL - Corpus Scriptorum Ecclesiasticorum Latinorum.

De vir. ill. - De viris illustribus.

Ep. - Epistula [Hilberg 1996].

Pref. In Apoc. - Praefatio In Apocalypsin.

\section{References}

\section{Primary sources}

Haussleiter, lohannes, ed. 1916. Victorini Episcopi Petavionensis Opera. CSEL 49. Vienna; Leipzig: F. Tempsky; G. Freytag.

Hilberg, Isidorus, ed. 1996. Hieronymus: Epistulae. CSEL 54, 55 and 56/1. Vienna: Verlag der Österreichischen Akademie der Wissenschaften.

\section{Secondary sources}

Avsenik Nabergoj, Irena. 2020. Izvori in strukture biblične pridige. Bogoslovni vestnik 80 , no. 3:519-536. DOI: 10.34291/BV2020/03/Avsenik.

Bogataj, Jan Dominik, and Miran Špelič. 2020. Krščanska in judovska skupnost v Ogleju skozi dela Fortunacijana in Kromacija. Edinost in dialog 75, no. 2: 141-165. DOI: 10.34291/Edinost/75/02/Bogataj.

Bogataj, Jan Dominik. 2020. Kristologija Fortunacijana Oglejskega: arijanska herezija ali nicejska ortodoksija? Bogoslovni vestnik 80, no. 4:715731. DOI: 10.34291/BV2020/04/Bogataj.

Curti, Carmelo. 1998. Girolamo e il millenarismo di Vittorino di Petovio. Annali di storia dell'esegesi 15, no. 1:191-203.
Dulaey, Martine. 1993. Victorin de Poetovio, premier exégète latin. 2 vols. Paris: Institut d'Études Augustiniennes.

Krašovec, Jože. 2020. Od simbola besede v Svetem pismo do teologije o opravičenju. Bogoslovni vestnik 80, no. 1: 49-61. DOI: 10.34291/ BV2020/01/Krasovec.

Micaelli, Claudio. 1995. Tertulliano nel quarto secolo: Vittorino di Pettau e Vittricio di Rouen. Studi Classici e Orientali 43:251-262.

Opelt, Ilona. 1965. Die lateinischen Schimpfwörter und verwandte sprachliche Erscheinungen: Eine Typologie. Heidelberg: Carl Winter.

- - - 1973. Hieronymus' Streitchriften. Heidelberg: Carl Winter. 